\section{Brandeis $\left.\right|_{\text {wrewer }}$}

brandeis.edu/j-caste
CASTE: A Global Journal on Social Exclusion

Vol. 1, No. 1, pp. 229-236

February 2020

ISSN 2639-4928

DOI: 10.26812/caste.v1i1.44

\title{
The Revolt of the Upper Castes
}

\author{
Jean Drèze'
}

\begin{abstract}
This article argues that the recent rise of Hindu nationalism in India can be seen as a revolt of the upper castes against the egalitarian demands of democracy. By and large, the upper castes have managed to retain their power and privileges in the post-independence period. Nevertheless, democratic institutions have forced them to accept some sharing of power and privilege in important spheres of public life. Some economic changes have also undermined their dominant position, at least in rural areas. The Hindutva project is a lifeboat for the upper castes, in so far as it stands for the restoration of the Brahminical social order that places them at the top. Seen in this light, the recent growth of Hindu nationalism is a major setback for the movement to annihilate caste and bring about a more equal society in India.
\end{abstract}

\section{Keywords}

Caste; Hindu nationalism; social inequality; social mobility; Hindutva.

\section{Introduction}

The recent growth of Hindu nationalism in India is a huge setback for the movement to annihilate caste and bring about a more equal society. The setback is not an accident: the growth of Hindu nationalism can be seen as a revolt of the upper castes against the egalitarian demands of democracy.

\section{Hindutva and Caste}

The essential ideas of Hindu nationalism, also known as 'Hindutva,' are not difficult to understand. They were explained with great clarity by V.D. Savarkar in Essentials of Hindutva (Savarkar, 1923), and amplified by other early Hindutva thinkers such as M.S. Golwalkar. The basic idea is that India belongs to the 'Hindus,' broadly defined in cultural rather than strictly religious terms that include Sikhs, Buddhists, and Jains but not Muslims and Christians (because the cradle of their

\footnotetext{
'Visiting Professor, Department of Economics, Ranchi University, Morabadi, Ranchi, India E-mail: jaandaraz@gmail.com
} 
religion is elsewhere). The ultimate goal of Hindutva is to unite the Hindus, revitalize Hindu society and turn India into a 'Hindu rashtra."

Incidentally, the arguments that were advanced to support these ideas involved startling departures from rational thinking, common sense, and scientific knowledge. Just to illustrate, consider Golwalkar's argument that all Hindus belong to one race, the Aryan race. Golwalkar did not have to contend, at that time, with the scientific evidence we have against that argument today, but he did grapple with an alleged discovery that Aryans came from somewhere north of India, in fact near the North Pole. He dealt with this claim by arguing that the North Pole itself used to be located in India:

'... the North Pole is not stationary and quite long ago it was in that part of the world, which, we find, is called Bihar and Orissa at the present;... then it moved northeast and then by a sometimes westerly, sometimes northward movement, it came to its present position... we were all along here and the Arctic zone left us and moved away northwards in its zigzag march.'

Golwalkar did not explain how the Aryans managed to stay in place during this 'zigzag march' of the North Pole. He used similarly contrived arguments to defend the odd claim that all Hindus share 'one language.'

The Hindutva project can also be seen as an attempt to restore the traditional social order associated with the common culture that allegedly binds all Hindus. The caste system, or at least the Varna system (the four-fold division of society), is an integral part of this social order. In We or Our Nationhood Defined, for instance, Golwalkar clearly says that the 'Hindu framework of society,' as he calls it, is 'characterized by varnas and ashrams' (Golwalkar 1939, p. 54). This is elaborated at some length in Bunch of Thoughts (one of the foundational texts of Hindutva), where Golwalkar praises the Varna system as the basis of a 'harmonious social order.' ${ }^{3}$ Like many other apologists of caste, he claims that the Varna system is not meant to be hierarchical, but that does not cut much ice.

Golwalkar and other Hindutva ideologues tend to have no problem with caste. They have a problem with what some of them call 'casteism'. The word casteism, in the Hindutva lingo, is not a reference to caste discrimination (like 'racism' is a reference to race discrimination). Rather, it refers to situations such as Dalits asserting themselves, or demanding special safeguards like reservation. That is casteism, because it divides Hindu society.

The Rashtriya Swayamsevak Sangh (RSS), the torch-bearer of Hindu nationalism today, has been remarkably faithful to these essential ideas. On caste, the standard line remains that caste is part of the 'genius of our country,' as the National General Secretary of the Bharatiya Janata Party, Ram Madhav, put it recently in Indian Express (Madhav, 2017), and that the real problem is not caste but casteism? ${ }^{4}$

An even more revealing statement was made by Yogi Adityanath, head of the BJP government in Uttar Pradesh, in an interview with NDTV two years ago. Much like Golwalkar, he explained that caste was a method for 'managing society in an orderly manner.' He said: 'Castes play the same role in Hindu society that furrows play in farms, and help in keeping it organised and orderly... Castes can be fine, but casteism is not...'5 
To look at the issue from another angle, Hindutva ideologues face a basic problem: how does one 'unite' a society divided by caste? The answer is to project caste as a unifying rather than a divisive institution. ${ }^{6}$ The idea, of course, is unlikely to appeal to the disadvantaged castes, and that is perhaps why it is rarely stated as openly as Yogi Adityanath did in this interview. Generally, Hindutva leaders tend to abstain from talking about the caste system, but there is a tacit acceptance of it in this silence. Few of them, at any rate, are known to have spoken against the caste system.

Sometimes Hindutva leaders create an impression that they oppose the caste system because they speak or act against untouchability. Savarkar himself was against untouchability, and even supported one of Dr. Ambedkar's early acts of civil disobedience against it, the Mahad satyagraha (Zelliott 2013, p.80). But opposing untouchability is not at all the same as opposing the caste system. There is a long tradition, among the upper castes, of defending the caste system along with opposing untouchability, often dismissed as a recent perversion of it. Gandhi himself argued that 'the moment untouchability goes, the caste system will be purified.'

\section{Uncertain Power}

The ideology of Hindu nationalism plays into the hands of the upper castes, since it effectively stands for the restoration of the traditional social order that places them at the top. As one might expect, the RSS is particularly popular among the upper castes. Its founders, incidentally, were all Brahmins, as were all the RSS chiefs so far except one (Rajendra Singh, a Rajput), and many other leading figures of the Hindutva movement - Savarkar, Hedgewar, Golwalkar, Nathuram Godse, Syama Prasad Mukherjee, Deen Dayal Upadhyay, Mohan Bhagwat, Ram Madhav, to name a few. Over time, of course, the RSS has expanded its influence beyond the upper castes, but the upper castes remain their most loyal and reliable base.

In fact, Hindutva has become a kind of lifeboat for the upper castes, as their supremacy came under threat after India's independence. By and large, of course, the upper castes have managed to retain their power and privileges in the postindependence period. Just to illustrate, in a recent survey of the "positions of power and influence' (POPI) (the university faculty, the bar association, the press club, the top police posts, trade-union leaders, NGO heads, and so on) in the city of Allahabad, we found that seventy-five per cent of the POPIs had been captured by members of the upper castes, whose share of the population in Uttar Pradesh is just sixteen per cent or so. Brahmins and Kayasthas alone accounted for about half of the POPIs. Interestingly, this imbalance was, if anything, more pronounced among civic institutions such as trade unions, NGOs, and the press club than in the government sector. Allahabad, of course, is just one city, but many other studies have brought out similar patterns of continued upper-caste dominance in a wide range of contexts - media houses, corporate boards, cricket teams, senior administrative positions, and so on. ${ }^{8}$

Nevertheless, the upper-caste ship has started leaking from many sides. Education, for instance, used to be a virtual monopoly of the upper castes - at the turn of the twentieth century, literacy was the norm among Brahmin men but virtually nil among Dalits. ${ }^{9}$ Inequality and discrimination certainly persist in the education system today, but in government schools at least Dalit children can claim the same status as uppercaste children. Children of all castes even share the same midday meal, an initiative that did not go down well with many upper-caste parents (Drèze, 2017). The recent 
introduction of eggs in midday meals in many states has also caused much agitation among upper-caste vegetarians. ${ }^{10}$ Under their influence, most of the states with a BJP government have been resisting the inclusion of eggs in school meals to this day.

The schooling system is only one example of a sphere of public life where the upper castes have had to resign themselves to some sharing of power and privilege. The electoral system is another example, even if 'adult suffrage and frequent elections are no bar against [the] governing class reaching places of power and authority,' as Dr. Ambedkar put it. ${ }^{11}$ The upper castes may be somewhat over-represented in the Lok Sabha (lower house of Parliament), but their share of it is a moderate twenty-nine per cent, in sharp contrast with the overwhelming upper-caste dominance of POPIs in society. At the local level, too, Panchayati Raj institutions and the reservation of seats for women, scheduled castes and scheduled tribes have weakened the grip of the upper castes on political affairs. Similarly, the judicial system restrains the arbitrary power of the upper castes from time to time (for instance in matters of land grab, bonded labour, and untouchability), even if the principle of equality before the law is still far from being realised.

Some economic changes have also undermined the dominant position of the upper castes, at least in rural areas. Many years ago, I had an opportunity to observe a striking example of this process in Palanpur, a village of Moradabad district in western Uttar Pradesh. When we asked Man Singh, a relatively educated resident of Palanpur, to write down his impressions of recent economic and social change in the village, here is what he wrote (in late 1983):

1. Lower castes are passing better life than upper castes. So there has been a great jealousy and hatefulness for lower castes in the hearts of upper caste people.

2. Ratio of education is increasing in low castes very rapidly.

3. On the whole, we can say that low castes are going up and upper castes are coming down; this is because the economic condition of lower castes seems better than higher castes people in the modern society.

I could not make sense of this until I understood that by 'lower castes,' Man Singh did not mean Dalits but his own caste, the Muraos (one of Uttar Pradesh's 'other backward classes'). With that clue, what he wrote made good sense, and indeed, it was consistent with our own findings: the Muraos, a farming caste, had prospered steadily after the abolition of zamindari and the onset of the Green Revolution - more so than the upper-caste Thakurs. Even as the Thakurs were struggling to keep the appearances of idle landlords (traditionally, they are not supposed to touch the plough), the Muraos were taking to multiple cropping with abandon, installing tubewells, buying more land and - as Man Singh hints - catching up with the Thakurs in matters of education. The Thakurs did not hide their resentment.

Palanpur is just one village, but it turns out that similar patterns have been observed in a good number of village studies. ${ }^{12}$ I am not suggesting that the relative economic decline of the upper castes is a universal pattern in rural India in the postindependence period, but it seems to be a common pattern at least. 
In short, even if the upper castes are still in firm control of many aspects of economic and social life, in some respects they are also losing ground, or in danger of losing ground. Even when the loss of privilege is relatively small, it may be perceived as a major loss.

\section{Striking Back}

Of all the ways upper-caste privilege has been challenged in recent decades, perhaps none is more acutely resented by the upper castes than the system of reservation in education and public employment. How far reservation policies have actually reduced education and employment opportunities for the upper castes is not clear - the reservation norms are far from being fully implemented, and they apply mainly in the public sector. What is not in doubt is that these policies have generated a common perception, among the upper castes, that 'their' jobs and degrees are being snatched by the scheduled castes, scheduled tribes and other backward classes (OBCs). ${ }^{13}$

As it happens, the revival of the BJP began soon after the V.P. Singh government committed itself to the implementation of the Mandal Commission report on reservation for OBCs, in 1990. This threatened not only to split Hindu society (the upper castes were enraged), but also to alienate OBCs - about forty per cent of India's population - from the BJP, opposed as it was to the Mandal Commission recommendations. L.K. Advani's Rath Yatra (chariot journey) to Ayodhya, and the events that followed (including the demolition of the Babri Masjid (mosque) on 6 December 1992), helped to avert this threat of 'casteism' and re-unite Hindus on an anti-Muslim platform, under the leadership of the BJP - and of the upper castes.

This is a striking example of Hindutva enabling the upper castes to counter a threat to their privileges and reassert their control over Hindu society. That, indeed, seems to be one of the main functions of the Hindutva movement today. The potential adversaries of this movement are not just Muslims but also Christians, Dalits, Adivasis, communists, secularists, rationalists, feminists, in short anyone who stands or might stand in the way of the restoration of the Brahminical social order. Though it is often called a majoritarian movement, Hindutva is perhaps better described as a movement of the oppressive minority.

One possible objection to this interpretation of the Hindutva movement (or rather, of its rapid growth in recent times) is that Dalits are supporting it in large numbers. This objection, however, is easy to counter. First, it is doubtful that many Dalits really support the RSS or Hindutva ideology. Many did vote for the BJP in recent elections, but that is not the same thing as supporting Hindutva - there are many possible reasons for voting for the BJP. Second, some aspects of the Hindutva movement may appeal to Dalits even if they do not subscribe to the Hindutva ideology. For instance, the RSS is known for its vast network of schools, and other kinds of social work, often focused on underprivileged groups. Third, the RSS has gone out of its way to win support among Dalits, not only through social work but also through propaganda, starting with the co-option of Dr. Ambedkar. Objectively speaking, there is no possible meeting ground between Hindutva and Dr. Ambedkar. Yet the RSS routinely claims him in one way or another.

Finally, it is arguable that even if Hindutva does not stand for the abolition of caste, its view - and practice - of caste is less oppressive than the caste system as it exists today. Some Dalits may feel that, all said and done, they are treated better in the 
RSS than in the society at large. As one RSS sympathiser puts it: 'Hindutva and the promise of a common Hindu identity always appealed to a large Dalit and OBC castes [sic] as it promises to liberate them from the narrow identity of a weaker caste, and induct them into a powerful Hindu community' (Singh 2019).

As mentioned earlier, the rise of Hindu nationalism should not be confused with the recent electoral success of BJP. Nevertheless, the sweeping victory of the BJP in the 2019 parliamentary elections is also a big victory for the RSS. Most of the top posts in government (prime minister, president, vice-president, speaker of the Lok Sabha, key ministries, many governors, and so on) are now occupied by members or former members of the RSS, firmly committed to the ideology of Hindu nationalism. The quiet revolt of the upper castes against democracy is now taking the form of a more direct attack on democratic institutions, starting with the freedom of expression and dissent. The retreat of democracy and the persistence of caste are in danger of feeding on each other.

\section{References}

Aggarwal, A., Drèze, J.P. and Gupta, A. (2015). Caste and the power elite in Allahabad. Economic and Political Weekly, 50(6), 7 February.

Ambedkar, B.R. (1945). What Congress and Gandhi have done to the untouchables. Bombay: Thacker \& Co.

Balagopal, K. (1990). This anti-Mandal mania. Economic and Political Weekly, 25(40), 6 October.

Drèze, Jean (2017). Sense and solidarity: Jholawala economics for everyone. Ranikhet: Permanent Black.

Drèze, J.P., Lanjouw, P., and Sharma, N.K. (1998). Economic development in Palanpur, 195793. In Lanjouw, P., and Stern, N. (Eds.), Economic development in Palanpur over five decades. Oxford: Oxford University Press.

Drèze, J.P., and Sen, Amartya (2013). An uncertain glory: India and its contradictions. London and New Delhi: Penguin.

Gandhi, M.K. (1933). Religion degraded. Harijan, 11 February 1933. Reprinted in Gandhi (1964), pp. 12-15.

Gandhi, M.K. (1964). Caste must go and the sin of untouchability, compiled by R.K. Prabhu. Ahmedabad: Navajivan Publishing House. Also available at www.gandhiheritageportal.org

Golwalkar, M.S. (1939). We or our nationhood defined. Nagpur: Bharat Publications.

Golwalkar, M.S. (1966). Bunch of thoughts. Bangalore: Vikrama Prakashan, Available at archive.org/stream/in.ernet.dli.2015.201991/2015.201991.Bunch-Of_djvu.txt

India Today (2019). Chhattisgarh BJP MLAs oppose eggs on mid-day meal menu in govt schools. Available at https://www.indiatoday.in/india/story/chhattisgarh-bjp-mlas-opposeeggs-on-mid-day-meal-menu-in-govt-schools-1571073-2019-07-18

Madhav, Ram (2017). Coming full circle at 70. Indian Express, 15 August.

Savarkar, V.D. (1923). Essentials of Hindutva, later reprinted under the title Hindutva: Who is a Hindu? Bombay: Veer Savarkar Prakashan. Available at savarkar.org/en/ encyc/2017/5/23/2_12_12_04_essentials_of_hindutva.v001.pdf_1.pdf

Singh, Abhinav Prakash (2019). A common Hindu identity has always appealed to OBC and Dalit castes. Hindustan Times, 18 July. 
Trivedi, P., Nissa, B.U., and Bhogale, S. (2019). From faith to gender and profession to caste: A profile of the 17th Lok Sabha. Hindustan Times, 25 May.

Zelliott, Eleanor (2013). Ambekdar's world: The making of Babasaheb and the dalit movement. New Delhi: Navayana.

\section{Endnotes}

1. The word 'rashtra' in this expression is difficult to translate. It encompasses not only nation and state, but also the social order.

2. Golwalkar (1939), p. 8 .

3. See Golwalkar (1966), pp. xxxi and 107-111. Golwalkar argues, inter alia, that the caste system continued "for thousands of years of our glorious national life. There is nowhere any instance of its having hampered the progress or disrupted the unity of society. It in fact served as a great bond of social cohesion' (p. 108).

4. The Bharatiya Janata Party (BJP), which leads the Indian government today, has a symbiotic relationship with the RSS. It can be considered as the political wing of the Sangh Parivar, a collection of organisations that are linked with the RSS and committed to Hindu nationalism.

5. Interview to NDTV, 5 March 2017 (available at https://www.youtube. $\mathrm{com} /$ watch? $\mathrm{v}=\mathrm{gE} 4 \mathrm{RONcQIUA)}$. K.S. Sudarshan, then sarsanghachalak (supreme leader) of the RSS, spoke in similar terms about the caste system being "like a fence around the farm" (quoted in Outlook, 27 January 2006; see https://www.outlookindia.com/newswire/story/caste-system-ensuredjob-quota-for-every-caste-rss-chief/351330).

6. Another possible answer is abolitionism - advocating the abolition of the caste system. That, however, would have alienated the upper castes.

7. To be fair, the 'caste system' Gandhi envisages here is very different from the caste system as it exists today: 'The moment untouchability goes, the caste system will be purified, that is to say, according to my dream, it will resolve itself into the true Varnadharma, the four divisions of society, each complementary of the other and none inferior or superior to any other, each as necessary for the whole body of Hinduism as any other.' (Gandhi 1933, pp. 14-15). How the removal of untouchability would ensure this 'purification' of the caste system, however, remains a mystery.

8. See the literature cited in Aggarwal, Drèze and Gupta (2015), where the findings of the Allahabad study are also presented in greater detail.

9. See 1901 Census figures presented in Drèze and Sen (2013), chapter 8. 
10. In fact, the state government's recent decision to add eggs in school meals is the subject of a major political battle in Chhattisgarh. BJP legislators, egged on by 'communities such as Kabir Panthi, Radha Soami, Gayatri Parivar, Jains and others,' are opposing the move in the State Assembly (India Today, 2019).

11. Ambedkar (1945), p. 208.

12. See Drèze, Lanjouw and Sharma (1998) on this literature, and also for a more detailed account of caste relations in Palanpur including the relative decline of the Thakurs.

13. This perception is well captured in a 1990 cartoon, mentioned by K. Balagopal (1990), where SC, ST and OBC students are standing on a ship and "grinning cruelly at the forward caste students who are sinking all round with their degree certificates held high". As Balagopal observes, 'it is difficult to imagine a more atrocious caricature of reality, which is almost exactly the opposite' (p. 2231). 